\title{
“Tourism Potentiality" as an Additional Activity for Socio-Economic Development of the Fishing Field in Las Aguamitas, Sinaloa, Mexico
}

\author{
Marcela Rebeca Contreras-Loera ${ }^{1}$, Elizabeth Olmos-Martínez ${ }^{2}$ \\ ${ }^{1}$ Economic Administrative Department, Universidad de Occidente, Culiacán, México \\ ${ }^{2}$ Department of Marine Biology in Coastal Ecology Laboratory Systems, Universidad Autónoma de Baja \\ California Sur. La Paz, Baja California Sur, México \\ Email: marcelac25@hotmail.com, eliolmos@gmail.com
}

Received 12 February 2014; revised 12 March 2014; accepted 30 March 2014

Copyright (C) 2014 by authors and Scientific Research Publishing Inc.

This work is licensed under the Creative Commons Attribution International License (CC BY). http://creativecommons.org/licenses/by/4.0/

c) (†) Open Access

\begin{abstract}
Riparian rural communities are characterized as spaces whose main activity is the exploitation of natural resources of the sea, but the diversification of economic activities is an option to change their current situation. The fishing cooperative plays a critical role in addressing the challenges imposed by the demands of today's world. It is necessary to implement practices that contribute to economic, social and ecological development of the locality. This paper presents results of research whose objective was to identify the tourism potentiality as a complementary activity to economic and social development of the rural community in Las Aguamitas and the role of the fishing cooperative Barra de La Tonina, in local community development. Data collection was conducted through semi-structured interviews and observation. In addition, a survey to characterize socioeconomically cooperative members was applied. The findings indicate that Las Aguamitas is a rural community with a wide range of natural and human resources to promote and encourage tourism. Even though the members of the cooperative and the community residents offer travel services, these are informal and without professionalization of the activity. From the above, it is concluded that the rural community has potential for tourism as a complementary activity for socioeconomic development, however it needs to train and professionalize the activity.
\end{abstract}

\section{Keywords}

Tourism, Rural Community, Socioeconomic Development, Cooperative 


\section{Introduction}

Rural areas are increasingly becoming an option for the closeness with nature and knowledge of rural sociocultural values. [1] notes that rural areas today meet with the characteristics of being new tourism scenarios, because, like natural areas, many of them are of high environmental quality, attracting avid visitor to contact with nature. [2] adds that the increased flow of tourists to rural areas and the growth of certain activities in these areas, targeting the "no" local inhabitants make it suitable to call these spaces as new tourism "scenarios".

Reference [1] believes that tourism in rural areas is a set of activities resulting from the visit to rural communities, building and enjoying the environment and its natural, cultural and socio-productive values. For this author, rural areas are characterized by the presence of rural communities, giving importance to the local community, turning them into the base for receiving tourist flows and the attractions that differentiate tourism activities in rural areas are based on natural resources, highlighting cultural values or sustained economic production of such spaces.

Tourism in rural communities adds value to the product in rural areas, rescuing and promoting the cultural and natural heritage of the communities in the game. The value of the spaces of rural communities is evidence of the influences balanced between abiotic, biotic and anthropic elements, where the energies that preserve nature, maintain and stabilize the landscape are both natural and human.

Reference [2] noted that 4 out of 5 of more than 172 million school children in the world live in rural areas, adding that rural areas are home to most of the world's poor people. On the other hand, [3] "Education for rural people and food security: a cross country analysis” shows that food security of rural children is closely linked to its access to education. Rural development should contribute to improving the welfare of people living in this environment, and overcoming unsustainable imbalances. Despite all this, international aid for rural areas has dropped two-thirds in recent decades: rural investments represented less than $10 \%$ of the commitments of the World Bank in 2000 [4].

Tourism could create alternatives to the participation of the host communities themselves, to diversify its activities and its economy with the creation and retention of jobs, for the rehabilitation of its architecture to the strengthening of rural activities and land, and for the recovery of the gastronomic traditions and its dissemination and promotion through these establishments. This strategic model aims not only to provide the necessary elements to strengthen the offered services, but also provide elements with which exploitation of the available resources are given progressively through different phases, in which the increase in demand causes the need to offer additional services, and to consolidate a comprehensive rural tourism product [5].

Reference [6] established that the cooperatives in the field of small-scale fisheries are a way to maximize the long-term community benefits, addressing the threats posed by poor management in the fisheries sector, insecurity in the media subsistence and poverty. Living in a situation of extreme food insecurity is the harsh reality for many of these fishermen around the world where 5.8 million of them earn less than a dollar a day being the ones who supply most of the fish consumed in the developed world.

Communities with community-based organizations are in a better economic position than those that do not have them. The successful cooperatives are possible, feasible and desirable and also play an important role in community development. Cooperatives have the potential to provide fishermen engaged in small-scale fisheries with the means to address environmental and socio-economic crisis as a decline in catches, disease, death, natural disasters or hunger in the family.

The small-scale fishing contributes more than half of the world catch of inland and marine fisheries, mostly intended for human consumption and employs over 90\% (33 million) of the total 36 million capture fishers throughout the world, with 107 million people in the development, distribution and marketing of fish. And approximately $47 \%$ of these people are women, who are particularly marginalized [6]. The growth of tourism that generates coastal and rural areas experience a remarkable transformation in the traditional productive activities lose weight compared to services.

In Mexico, [7] head of the Secretaría de Agricultura, Ganadería, Desarrollo Rural, Pesca and Alimentación (Ministry of Agriculture, Livestock, Rural Development, Fisheries and Food) said that the fishing cooperatives provide nearly $50 \%$ of maritime and aquaculture production for human consumption of the Mexicans. He also commented that in the fisheries sector, the country's cooperatives have been formed and strengthened as a specific business model that currently has 3327 associations, bringing together 167,000 fishermen and farmers.

Reference [5], to seek an alternative income for rural communities reflects the need to revive and strengthen 
the economy of these areas. Currently, most of them are limited to the development of primary activities, causing lower income for them and causing that the young tends to migrate and therefore the human potential decreases.

From the above, the main objective of the study was to identify the tourism potentiality as a complementary activity to economic and social development for the rural community in Las Aguamitas and the role of the fishing cooperative Barrra La Tonina, in local community development.

\section{Methodological References}

This research is with an analytic descriptive purpose, it was conducted in the fishing community Las Aguamitas, considering the cooperative fishing role as a touristic agent, with the purpose of analyze the natural resources, materials and infrastructure available to the community in order to identify the touristic activity potential. The study was conducted during the year of 2013.

The research includes qualitative variables; data collection was through interviews addressed to managers of the fishing cooperative Barra de La Tonina (current and former), key people from the community and the authority from the community (commissary) and from the city of Navolato (Director of Economic Development); likewise a direct observation in the community was done. Furthermore, the documentary research consisted of the analysis of internal documents of the cooperative, as well as from reports from the city and state government. Complementarily 100 surveys were applied to members of the cooperative Barra de La Tonina, in order to characterize socioeconomically the fishermen that integrate it.

This allowed describing and analyzing the relevance and potentiality (social, economic and environmental) of performing touristic activity as a complementary part of the fishing activity in the community of Las Aguamitas, Sinaloa, Mexico.

\section{Empirical Results}

The rural community of Las Aguamitas is located in the town of Navolato (85\% of the population lives in rural areas and is divided into 301 communities) in the state of Sinaloa in Mexico. Sinaloa is leader in the offshore shrimp fishery and riparian. It has the largest fishing fleet in the north of the country, due to 18,116 registered vessels, of which 769 are for high sea and 17,347 are dedicated to the waterfront and inland fisheries, also has 500 cooperative societies operated for offshore fishermen as riparian and freshwater. Fishing and aquaculture from Sinaloa are renowned for their volume and quality of production, with a workforce of 44,802 people [8].

The fisheries and aquaculture production is critical for the country and the state, because the state of Sinaloa contributes $20 \%$ of the volume of national fish production and $24 \%$ in value terms. Fisheries and aquaculture, represents 4\% of the state GDP. In 2012, Sinaloa ranked first in Mexico for the fishing of shrimp, tuna, crab and shark, also stood at the second position in shrimp aquaculture production.

Las Aguamitas is one of the 254 fishing communities in Sinaloa. It has a population of 1629 inhabitants, 52\% male and $48 \%$ female [9], the main economic activity is fishing various species of crustaceans (shrimp, crabs), molluscs (clam, oyster), flake (snook, snapper, curbina, puffer fish).

In Sinaloa, the fishing activity for some species is carried out in an organized manner through the integration of fisheries cooperatives; 141 fishing cooperatives are currently operating, which is dedicated to catching various species of both bay and offshore. Due to the nature of the activity and the demographic structure, the sector registered a strong informal activity in both coastal and inland waters.

In Las Aguamitas, there are currently two fishing cooperatives registered: 1) Sociedad Cooperativa de Producción Pesquera Barra de La Tonina, S.C.L. de C.V.; 2) Sociedad Cooperativa de Producción Pesquera David Porter, S.C.L. de C.V. These cooperatives are active in response to various norms that regulate their work, such as Ley General de Sociedades Cooperativas; Ley de Pesca; Ley de Aguas Nacionales y su Reglamento; Ley General del Equilibrio y la Protección al Ambiente (General Cooperative Societies Act, Fisheries Act, Water Law and Regulations, General Law of Equilibrium and Environmental Protection); Normas Oficiales Mexicanas (Mexican Official Standards) regulate the exploitation of sea species, among others.

This research addressed the case of the fishing cooperative Barra de La Tonina and their role in the development of tourism potentiality as an alternative for the rural community. The fishing cooperative, Barra de la Tonina, was founded on April 9, 1987, from the interest of a group of 197 fishermen belonging to the cooperative David Porter (founded in 1960), nevertheless currently is comprised of 195 members. 
It has a federal government grant for extraction, capture and commercial use of the estuary shrimp species (Penaeus spp.) until 2014, in federal waters of the lagoon system Bahía Altata and Ensenada del Pabellón (41,200 hectares). The concessions entitles them to capture and extract estuary shrimp according to ages, sizes, and fishing gear and catch volumes that define the authorities, industrialize and market catches and operates the concession species during each fishing season teams and fishing gear authorized. Generally the capture takes place from September to March, as established by the authority, as the shrimp is one of the species in Mexico that is more controlled by closed, in order to ensure that the crustacean fulfill its biological cycle reproduction.

The ban implemented by the Mexican Federal Government aims to comply with the national policy of sustainable use of natural resources and regulatory instruments that are established to protect marine species from Mexico.

This implies that from April to August is prohibited to fish shrimp and during this period 93\% of the members of the cooperative develops alternative activities such as fishing of various species, $60 \%$ offer services like boat ride or tours around the estuaries and islands and $40 \%$ offer services of sport fishing (Figure 1) complementing their income with the development of masonry and carpentry activities.

The partners have experience as fishermen between 10 and 25 years, their ages ranging between 30 and 40 years (47\%) and 40 - 50 years (34\%), 85\% of the members are married and have 1 to 3 sons/daughters, some of them have finished high school (36\%), primary school (51\%), and only $2 \%$ have professional studies. The cooperative members not only have experience and knowledge about the ecosystem of the field, they also have the equipment for tourism development in the field. $72 \%$ of respondents have a fiberglass boat and $60 \%$ of them have outboard motor (Table 1).

In relation to tourism in the community, the type and volume of visitors to the community are mainly domestic, especially from the municipality of Culiacan and Navolato. To date there is no record of the number of visitors; the fishermen said they receive about hundred visitors per month, including swimmers, walkers and fishermen. They also receive tourists who practice sport fishing.

On the other hand, an inventory of natural areas and recreational benefits was performed for the touristic activities that are performed and that are potentially susceptible to an orderly and sustainable advantage, as well as an income generator for the families of the cooperative, likewise the services that offer the members of the cooperative and its inhabitants were identified, to the people who visit the community (Table 2).

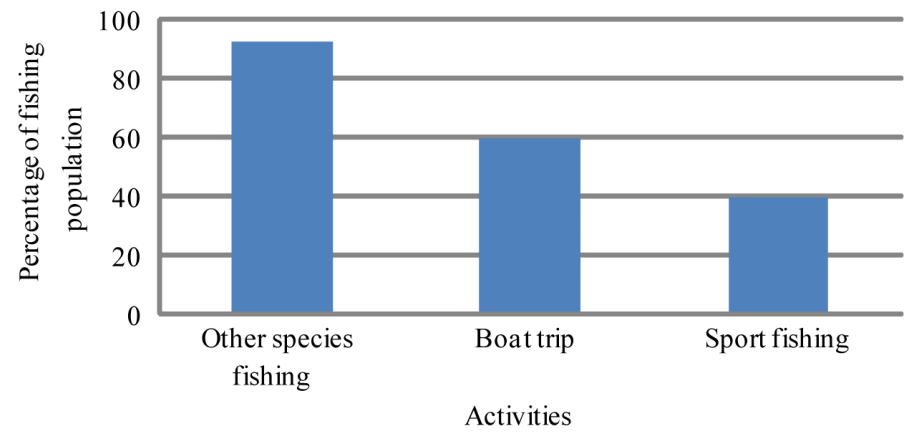

Figure 1. Alternative activities in the months of April to August (closed shrimp season).

Table 1. Characteristics of the population.

\begin{tabular}{cc}
\hline Characteristics & Population \\
\hline $\begin{array}{c}\text { Average antiquity in fishing activity } \\
\text { Between } 30 \text { and } 40 \text { years old }\end{array}$ & Between 10 and 25 years \\
Marital status Married & $47 \%$ of the population \\
Elementary studies & $85 \%$ of the population \\
Fiberglass boat & $51 \%$ of the population \\
Outboard motor & $72 \%$ of the population \\
\hline
\end{tabular}


Table 2. Inventory of natural areas and recreational benefits.

\begin{tabular}{|c|c|c|c|c|}
\hline Natural area & Natural resources & Recreational benefit & Services offered & Potential activities \\
\hline Oporito Beach & $\begin{array}{l}\text { Marine mammals, fish and } \\
\text { invertebrates, sand dunes }\end{array}$ & $\begin{array}{l}\text { Beach day, camping, walking } \\
\text { (road trip), scuba diving }\end{array}$ & Tent & \multirow{5}{*}{$\begin{array}{l}\text { Observation of flora } \\
\text { and fauna } \\
\text { Environmental } \\
\text { education workshop } \\
\text { Photographic Safari } \\
\text { Scuba diving Kayak } \\
\text { Mystical experiences } \\
\text { Aquatic ski } \\
\text { Rural photography }\end{array}$} \\
\hline Las Navajas Beach & $\begin{array}{l}\text { Marine mammals, fish and } \\
\text { invertebrates, sand dunes }\end{array}$ & $\begin{array}{l}\text { Beach day, camping, walking } \\
\text { (road trip), scuba diving }\end{array}$ & Tent & \\
\hline $\begin{array}{l}\text { La Camarga y Las } \\
\text { Ventanas Beach }\end{array}$ & $\begin{array}{l}\text { Marine mammals, fish and } \\
\text { invertebrates, sand dunes }\end{array}$ & $\begin{array}{l}\text { Beach day, camping, walking } \\
\text { (road trip), scuba diving }\end{array}$ & Tent & \\
\hline $\begin{array}{l}\text { Las Aguamitas } \\
\text { Bay }\end{array}$ & $\begin{array}{l}\text { Aquatic birds, marine } \\
\text { mammals (bottlenose dolphin), } \\
\text { invertebrates, species for } \\
\text { sport fishing }\end{array}$ & $\begin{array}{l}\text { Birdwatching, beach day, } \\
\text { sighting of marine mammals } \\
\text { (bottlenose dolphin), } \\
\text { sport fishing }\end{array}$ & $\begin{array}{l}\text { Boat trip, selling } \\
\text { fresh sea products, } \\
\text { selling food }\end{array}$ & \\
\hline Media luna Marsh & $\begin{array}{l}\text { Low swampy ground, } \\
\text { mangrove, terrestrial } \\
\text { mammals and birds }\end{array}$ & $\begin{array}{l}\text { Birdwatching and terrestrial } \\
\text { mammals, marine mammals, } \\
\text { sport fishing }\end{array}$ & $\begin{array}{l}\text { Boat trip, selling } \\
\text { fresh sea products, } \\
\text { selling food }\end{array}$ & \\
\hline
\end{tabular}

It has resident wildlife and marine mammals (dolphin, marine reptiles) and terrestrial, marine and terrestrial birds, fish and invertebrates, crustaceans, molluscs, annelids. Within the group of birds with terrestrial habits have been identified four families, with eleven types and equal number of species (white-winged dove, dove, black thrush, Cardinal Woodpecker, Siskin musketeer, etc.). It is possible to observe aquatic birds such as the cormorant, heron golden fingers, the blue heron, and duck diving, among others. There is about 25 migratory species, some kinds are those known as shorebird, from the kind of Anas, Aythya and Anser.

One of the main attractions of the community is the sighting of bottlenose dolphins (Tursiops truncatus) which is located in the category as "Protected" according to NOM-059-SEMARNAT-2001. The bottlenose dolphin is a variety of coastal habits who likes to follow nearby the crafts. Usually, these dolphins are seen in groups of 2 - 4 animals at the mouth of the Bahía de Las Aguamitas (Bay of Las Aguamitas) in areas with up to three meters deep. Fishermen often hit their boat with a thick log because that noise make the dolphins to approach so people may be able to touch them and even swim among them.

On wildlife, there are four different types of mangroves: red, ashen, white and black. The red mangrove is distributed by the tidal channel to the beach, which requires frequent flooding; ashen mangrove bordered on board the tidal channel to inland which requires periodic flooding and shallow water, the black mangrove is mixed with ashen mangroves and requires more sporadic tidal flooding, the white mangrove demand land but does not require tidal flooding.

Regarding services for tourists, the community offers rides to fish, fishing competitions (since 2005 sportfishing sailfish, swordfish and Goldfish, becoming an alternative employment generating attractive returns for fishermen that practice) however they recognized that the tours performed are scarce. On the other side, fishermen members of the cooperative do not homologate fishing criteria, care and cost of services. There is not a module to offer attention to the visitors. Tourists arrive looking for those fishermen they already know for tours in the estuary and to the open sea.

One of the main attractions for visitors to the community is buying fresh sea products in their natural state (especially shrimp and finfish species). These activities directly benefits the fisherman and his family, and indirectly to small businesses offering products for food preparation in the fisheries field, raising the incomes of the inhabitants.

During the year, the people of the community perform various parties where the influx of visitors increases, these festivals are: Fiesta de Semana Santa, Torneo de Pesca Anual and Fiesta del Día del Marino (Easter weekend, the annual fishing tournament and the holyday of the sailor).

The inhabitants of the field as well as the Director de Desarrollo Económico de Navolato (Director of Economic Development of Navolato) say that the field has sufficient natural and social resources to be exploited in the development of tourism. However, they agree that the government currently does not provide support for this community to promote and boost tourism as an alternative for local development.

\section{Conclusions}

In Sinaloa, the main economic activities take place in the primary sector activities (agriculture, fisheries and 
tourism), which are concentrated in the coastal area, where the environment is diverse and gradually transformed by the pressure of the human activities, causing ecological imbalance to be avoided, prevented or corrected.

Las Aguamitas is a community located in a rural area, the main economic activity of the people is the exploitation of the natural resources from the sea (especially shrimp and finfish species). The fishing activity is organized through fishing cooperatives, however, they are currently facing problems of over-exploitation of fishing resources, the fishing fleet overcapacity, increasing population in the fishing camps and poaching and lack of strict enforcement of fisheries management. This generates the need to consider options for promoting economic and social development of communities.

The fishing camp of Las Aguamitas welcomes visitors on weekdays and the number of them usually increases on weekends and during the Easter period. It offers a diverse range of natural resources that represent an attraction for the visitor preferences for contact with nature, and the community has natural resource inventory of flora, fauna, beaches and estuaries, among others; all of them are available for tourists. Nevertheless, the influx of visitors is uneven and the number of people who develop activities to meet the tourists' needs is insufficient.

Residents and members of the fishing cooperative Barra de La Tonina develop tourism-related activities, informally, because they are not professionally trained to attend to visitors. It is carried out from their experiences and perceptions of care to visitors, and tourist service is carried out with the equipment used for fishing, but they do not have the equipment to ensure the safety of tourists, which indicates the need to promote and encourage tourism as an economic activity that provides opportunities for generating additional income besides fishing and thereby improving the current situation of the population.

Las Aguamitas has human capital and natural resources to promote tourism. On the one hand, natural resources represent an attraction for tourists, becoming the main reason to visit the fishing camp and on the other hand, the role of the cooperative as a travel agent is important because they are the ones with maritime equipment and experienced in maritime areas to provide the services demanded by tourists when it comes to coastal rural areas. However, you need to professionalize the business to exploit the potential offered by tourism as a complementary activity to promote the socioeconomic development of rural community.

\section{References}

[1] Viñals, B.M.J. (2002) Turismo en Espacios Naturales y Rurales II. Universidad Politécnica de Valencia, Valencia, 105-106. http://books.google.com.mx/books?id=nBYc11eTVK0C\&printsec=frontcover\#v=onepage\&q\&f=false

[2] Vilches, A., Gil Pérez, D., Toscano, J.C. and Macías, O. (2009) Desarrollo Rural. http://www.oei.es/decada/accion.php?accion=022

[3] De Muro, P. and Burchi, F. (2007) Education for Rural People and Food Security a Cross Country Analysis. Food and Agriculture Organization of the United Nations, Rome. ftp://ftp.fao.org/docrep/fao/010/a1434e/a1434e.pdf

[4] Halweil, B. (2002) Una Agricultura en Interés de Todos. In: La situación del mundo 2002. Informe Anual del The World watch Institute sobre Progreso hacia una Sociedad Sostenible. Icaria Editorial, Barcelona, 103. http://www.fuhem.es/media/cdv/file/biblioteca/Situaci\%F3n\%20del\%20Mundo/Situaci\%F3n\%20del\%20Mundo\%202 002.pdf

[5] Hernández, T.I. (2010) Turismo Rural en México como Estrategia para la Recuperación y Fortalecimiento. Consultoría Estratégica Integral.

http://www.blogdeturismorural.com.ar/2010/09/18/turismo-rural-como-estrategia-para-la-recuperacion-y-fortalecimien to-del-turismo-en-mexico

[6] FAO (Food and Agriculture Organization of the United States) (2009) Las Cooperativas en la Pesca en Pequeña Escala: Favorecer el Éxito Mediante el Empoderamiento ee la Comunidad. http://www.fao.org/docrep/016/ap408s/ap408s.pdf

[7] Mayorga, C.F. (2012) Cooperativas Pesqueras y Acuícolas, Clave Para Alimentar al Mundo. Secretaría de Agricultura, Ganadería, Desarrollo Rural, Pesca y Alimentación de México. Conferencia en el Foro Económico de Pesca y Acuacultura, Mazatlán, Sinaloa. http://www.conapesca.sagarpa.gob.mx/wb/cona/15 de octubre de 2012 mazatlan sinaloa2

[8] Instituto Nacional de Estadística, Geografía e Informática (2010) Población Rural y Urbana. http://cuentame.inegi.org.mx/monografias/informacion/sin/poblacion/distribucion.aspx?tema=me\&e=25

[9] Trujillo, B.P. and Lopez, G.M.D. (2011) Catálogo de Recursos Acuáticos de Importancia Económica del Estado de Sinaloa. México. Gobierno del Estado de Sinaloa. 